\title{
Effect of two processing techniques used to manufacture lithium disilicate ceramics on the degree of conversion and microshear bond strength of resin cement
}

\author{
Amauri C. Drumond', Eloisa A. C. Paloco' ', Sandrine B. Berger', Alejandra H. M. González', \\ Artur J. Carreira², Paulo H. P. D’Alpino², Mateus R. Tonetto³, Lorena A. Souza³, Ricardo D. \\ Guiraldo' \\ ' Universidade Pitágoras Unopar - UNOPAR, Faculdade de Odontologia, Departamento de Odontologia Restauradora, \\ Londrina, PR, Brasil \\ 2 Universidade Anhanguera de São Paulo - UNIAN-SP, Programa de Biotecnologia e Inovação em Saúde, São Paulo, SP, \\ Brasil \\ ${ }^{3}$ Universidade de Cuiabá - UNIC, Faculdade de Odontologia, Departamento de Odontologia, Cuiabá, MT, Brasil
}

\begin{abstract}
The aim of the current study was to compare the effect of two lithium disilicate ceramic processing techniques (pressing and $C A D / C A M)$ on the degree of conversion of resin cement when it is photoactivated and the microshear bond strength of resin cement to ceramics. Two ceramic discs were manufactured: one by the Press technique and another by CAD/CAM technique. Five Variolink Veneer resin cement samples were photoactivated through each ceramic disc and subjected to attenuated total reflectance Fourier transform infrared spectroscopy to evaluate their degree of conversion. To evaluate microshear bond strength, 20 ceramic bars were prepared: 10 using the Press technique and 10 using the CAD/CAM technique. The bars were air abraded with 50-um $\mathrm{Al}_{2} \mathrm{O}_{3}$ particles, treated with $10 \%$ hydrofluoric acid for $20 \mathrm{~s}$ and subjected to RelyX Ceramic Primer application. Adper Scotchbond Multi-Purpose Adhesive was applied to the bars and cured for $10 \mathrm{~s}$. Two 1-mm-height plastic tubes were
\end{abstract}

placed on each bar and filled with Variolink Veneer resin cement. Each cylinder was cured for $20 \mathrm{~s}$. Then the plastic tubes were removed and the microshear bond strength of each cylinder was tested. Data for degree of conversion (\%) and microshear bond strength (MPa) were subjected to Student's t-test $(\alpha=$ 0.05). Both degree of conversion of resin cement photoactivated through ceramic and microshear bond strength of resin cement to ceramic were statistically higher in the group in which ceramic was prepared by CAD/CAM technique $(44.74 \%$ and $22.18 \mathrm{MPa})$ than in the group in which the ceramic was prepared by the Press technique (25.71\% and $19.83 \mathrm{MPa})$. The lithium disilicate ceramic processing techniques affected the degree of conversion of resin cement when it is photoactivated through the ceramics and the microshear bond strength of resin cement to ceramics. Received: March 2020; Accepted: May 2020

Keywords: ceramics-resin cements-cementation- polymerization.

\section{Efeito de duas técnicas de processamento utilizadas na fabricação da cerâmica de dissilicato de lítio no grau de conversão e na resistência de união ao microcisalhamento do cimento resinoso}

\begin{abstract}
RESUMO
O objetivo do presente estudo foi comparar o efeito de duas técnicas de processamento da cerâmica de dissilicato de litio (prensada e CAD/CAM) no grau de conversão do cimento resinoso quando fotoativado e na resistência de união ao microcisalhamento do cimento resinoso às cerâmicas. Foram fabricados dois discos de cerâmica: um pela técnica prensada e outro pela técnica CAD/CAM. Cinco amostras de cimento resinoso Variolink Veneer foram fotoativadas através de cada disco cerâmico e submetidas à espectroscopia no infravermelho por transformada de Fourier com reflectância total para avaliar seu grau de conversão. Para avaliar a resistência de união ao microcisalhamento, foram preparadas 20 barras de cerâmicas: 10 utilizando a técnica prensada e 10 utilizando a técnica CAD/CAM. As barras foram tratadas com
\end{abstract}

partículas de $\mathrm{Al}_{2} \mathrm{O}_{3}(50 \mu \mathrm{m})$, com ácido fluorídrico a $10 \%$ por 20 s e submetidas à aplicação do RelyX Ceramic Primer. Em seguida, o adesivo multiuso Adper Scotchbond foi aplicado nas barras e fotoativado por $10 \mathrm{~s}$. Dois tubos de plástico de $1 \mathrm{~mm}$ de comprimento foram colocados em cada barra e preenchidos com cimento resinoso Variolink Veneer. Cada cilindro foi fotoativado por $20 \mathrm{~s}$. Os tubos de plástico foram removidos e a resistência de união ao microcisalhamento de cada cilindro foi testada. Os dados de grau de conversão (\%) e resistência de união ao microcisalhamento (MPa) foram submetidos ao teste $t$ de Student $(\alpha=0,05)$. Tanto o grau de conversão do cimento resinoso fotoativado através da cerâmica quanto a resistência de união do cimento resinoso à cerâmica foram estatisticamente maiores no grupo em que a cerâmica foi confeccionada pela técnica CAD/CAM 
(44,74\% e 22,18 MPa) do que no grupo em que a cerâmica foi confeccionada pela técnica prensada $(25,71 \%$ e 19,83 $\mathrm{MPa}$ ). As técnicas de processamento de cerâmica dissilicada de lítio afetaram o grau de conversão do cimento resinoso quando fotoativado através das cerâmicas e a resistência

\section{INTRODUCTION}

The global demand for ideal dental aesthetics is based on the assumption that beauty is associated with favorable personality traits ${ }^{1}$. Ceramics are used in dentistry as aesthetic restorative materials due to their satisfactory mechanical properties such as high compressive strength, chemical stability, low electrical conductivity, thermal diffusivity, translucency, fluorescence, biocompatibility (they provide low solubility, reduce plaque accumulation and enable sufficient marginal adjustment), favorable aesthetic properties and thermal expansion coefficient similar to that of tooth structure ${ }^{2,3}$. However, the brittle nature of ceramics has led to high fracture rates, mainly in the case of glassceramic systems placed in the posterior region ${ }^{4}$.

Lithium disilicate glass-ceramic system is a unique material with microstructure interconnected with lithium disilicate crystals similar to needles making up to $70 \%$ volume incorporated into a glassy matrix ${ }^{5}$. It is used in indirect restorations to emulate the aesthetics and natural resistance of dental structures $^{6}$. It provides translucency similar to that of natural teeth and biaxial resistance of up to 400 $\mathrm{MPa}$, which is almost three times higher than that of conventional glass ceramics 5 . The use of ceramic veneers in dentistry has increased due to high degree of aesthetic requirements, since lithium disilicate facets can restore dental aesthetics by making the restoration look very similar to the natural dental structure. Moreover, it requires less invasive preparations or even no cavity preparation at all ${ }^{7}$. The aesthetic quality of the material is not the only criterion to be taken into consideration to ensure successful restoration procedures. Ceramic veneers must be firmly attached to the dental structure by resin cements in order to ensure good strength, aesthetics and clinical longevity ${ }^{8,9}$.

According to their polymerization method, resin cements can be classified as chemically activated, physically activated or dual activation (dual cement), which combines both activation forms. Light-activated resin cements are the material of choice in situations such as cementation of de união do microcisalhamento do cimento resinoso às cerâmicas.

Palavras-chave: cerâmica- cimentos de resina-cimentaçãopolimerização.

ceramic veneers due to their color stability and long working time ${ }^{10}$. However, the maximum degree of conversion (DC) of light-activated resin cement cannot be ensured in situations where light has been attenuated. Insufficient degree of conversion can adversely affect the mechanical properties, change the dimensional stability and decrease bond strength between resin cements and dental and ceramic structures, thereby impairing the clinical longevity of restorations ${ }^{11}$. Accordingly, based on the aforementioned assumptions, further studies are needed to clarify the effect of processing techniques of the lithium disilicate-based restoration on the degree of conversion and bond strength of resin cement. The aim of the current study was thus to compare the effect of two lithium disilicate ceramic processing techniques (pressing and $\mathrm{CAD} /$ CAM [Computer Aided Design/Computer Aided Machining]) on the degree of conversion of resin cement when it is photoactivated and the microshear bond strength of resin cement to ceramics. The null hypotheses are that there is no difference between the two processing techniques regarding either [1] the degree of conversion of resin cement or [2] the microshear bond strength of resin cement to ceramics.

\section{MATERIALS AND METHODS}

\section{Ceramic disc and bar Preparation}

Two discs (10 $\mathrm{mm}$ diameter by $0.6 \mathrm{~mm}$ thick) and twenty bars $(6.5-\mathrm{mm}$ long x 5-mm wide x 1 -mm thick) were manufactured in lithium disilicate glass ceramic. One disc and 10 bars were based on the manufacturing technique applied to lithium disilicate ceramic indirect restorations, followed by the automation technique guided by the CAD/CAM system (IPS e.max CAD; Ivoclar Vivadent, Schaan, Liechtenstein), while the other disc and 10 bars were prepared by isostatic injection based on heat technology (IPS e.max Press; Ivoclar Vivadent), both in shade LT A1. The resulting discs were subjected to sequential wet polishing with silicon carbide abrasive papers $(320,400,600$ and 1200 
grit; Norton SA, São Paulo, SP, Brazil) in a watercooled automatic polisher (APL4; Arotec, Cotia, SP, Brazil), to achieve their final diameter $(10 \mathrm{~mm})$ and thickness $(0.5 \mathrm{~mm})$, and cleaned ultrasonically with distilled water for $10 \mathrm{~min}$ and dried with compressed air. Disc thickness was measured with a $0.01 \mathrm{~mm}$ accuracy digital caliper (Mitutoyo Corporation, Tokyo, Japan).

The LED curing unit output (Radii Cal; SDI, Bayswater, Victoria, VIC, Australia) was measured with a power meter (Ophir Optronics Inc., Danvers, MA, USA) at irradiance $1200 \mathrm{~mW} / \mathrm{cm}^{2}$.

\section{Measurement of degree of conversion in resin cement}

For analysis of degree of conversion, 10 cylindrical specimens were prepared by inserting Variolink Veneer light-curing resin cement (Ivoclar-Vivadent, shade HV+1) into a mold (1.0 mm deep / $7 \mathrm{~mm}$ diameter). Specimens were divided into two groups and cured for $20 \mathrm{~s}$ either through the CAD/CAM ceramic disc $(\mathrm{n}=5)$ or through the Press ceramic disc $(n=5)$. Then they were washed in distilled water, dried with absorbent paper, placed in containers and stored at $37^{\circ} \mathrm{C}$ for 24 hours.

The unpolymerized resin cement was accessed twice in order to set the bonding pattern of its monomeric state before sample analysis. Subsequently, all specimens were analyzed through Fourier Transform Infrared Spectroscopy - FTIR (Spectrum 100 Optica; Perkin Elmer, MA, USA), with attenuated total reflectance (ATR), using horizontal Zinc Seleneto crystal (Pike Technologies, Madison, WI, USA), which acted as active substrate for the infrared rays.

Graphs were generated in the Spectrum software version 6.3.1 (PerkinElmer) for visualization and analysis. The FTIR spectrometer operated under the following conditions: $300-4000 \mathrm{~cm}^{-1}$ wavelength, $4 \mathrm{~cm}^{-1}$ resolution and 16 scans. Degree of conversion (DC) was calculated by comparing the aliphatic carbon-carbon double bond ratio $(\mathrm{C}=\mathrm{C})$ at $1640 \mathrm{~cm}^{-1}$ and $\mathrm{C}=\mathrm{O}$ at 1710 $\mathrm{cm}^{-1}$ in cured and uncured materials, based on the following equation: DC $(\%)=$ (polymerized $1-\mathrm{R}$ / unpolymerized R) X 100; wherein $\mathrm{R}=$ peak at $1640 \mathrm{~cm}^{-1} /$ peak at $1710 \mathrm{~cm}^{-1}$. These calculations were carried out in Microsoft Office Excel 2007 software (Microsoft Office Professional Edition 2007, Microsoft Corporation).

\section{Measurement of microshear bond strength}

The bars were separated into two groups - Press ceramic group $(\mathrm{n}=10)$ and $\mathrm{CAD} / \mathrm{CAM}$ ceramic group $(\mathrm{n}=10)$ according to the manufacturing method. Bars were wet polished with 600- and 1200grit silicon carbide abrasive papers (Norton SA, São Paulo, SP, Brazil) to produce a flat surface, dried, and air-abraded with $50 \mu \mathrm{m} \mathrm{Al}_{2} \mathrm{O}_{3}$ particles (Bioart, São Carlos, SP, Brazil). Then they were ultrasound cleaned in distilled water for $10 \mathrm{~min}$ and dried again. Subsequently, they were treated with $10 \%$ hydrofluoric acid for $20 \mathrm{~s}$ (Dentsply, Petrópolis, RJ, Brazil), subjected to RelyX Ceramic Primer (3M ESPE, St. Paul, MN, USA) application for $60 \mathrm{~s}$ and thoroughly air-dried. Adper Scotchbond MultiPurpose Adhesive (3M ESPE) was applied with microbrush to all pretreated ceramic surfaces for 20 $\mathrm{s}$, which were then thoroughly air thinned for $10 \mathrm{~s}$ and cured with LED curing light (Radii-Cal; SDI, Bayswater, VIC, Australia) at $1200 \mathrm{~mW} / \mathrm{cm}^{2}$ for 10 $\mathrm{s}$ through their respective ceramic disc, according to each processing technique. Two transparent cylindrical molds (Tygon tubing - TyG-03; SaintGobain Performance Plastic, Maime Lakes, FL, USA) (height $1 \mathrm{~mm}$; internal diameter $0.75 \mathrm{~mm}$ ) were positioned on the surface of each bar $^{12}$. A \#5 exploratory probe (Hu-Friedy, Chicago, IL, USA) was used to apply the resin cement inside the molds. Each resin cement cylinder (two cylinders per bar) was photoactivated for $20 \mathrm{~s}$ through its respective ceramic disc and stored in distilled water at $37{ }^{\circ} \mathrm{C}$. Twenty-four (24) hours later, the molds were removed with the aid of a scalpel blade to expose two cement cylinders with a bond area of $0.38 \mathrm{~mm}^{2}$ (each). Bars were mounted on a steel device in a universal testing machine (DL2000; Emic, São José dos Pinhais, PR, Brazil). Load was applied at the base of the cylinder with the aid of a steel wire $(0.2 \mathrm{~mm}$ diameter) at speed of $0.5 \mathrm{~mm} / \mathrm{min}$ until fracture to determine the microshear bond strength. Each group contained 10 bars and each bar had two cylinders, providing a total of 20 cylinders per group. The average between the two cylinders on each bar was considered a specimen.

\section{Statistical Analysis}

Data were subjected to statistical analysis in the SAS System for Windows 9.0 (SAS Institute Inc., Cary, NC, USA). Measurement distribution was subjected to Kolmogorov-Smirnov test, after which 
parametric tests were used. Degree of conversion (\%) and microshear bond strength values (MPa) were subjected to Student's t-test, at 5\% significance level.

\section{RESULTS}

Table 1 shows the mean values for degree of conversion and microshear bond strength. The mean of degree of conversion of resin cement was statistically higher when photoactivated through ceramic prepared with the $\mathrm{CAD} / \mathrm{CAM}$ processing technique than through ceramic prepared with the Press processing technique. The microshear bond strength of resin cement was statistically higher when bonded to ceramic prepared with the CAD/ CAM processing technique than ceramic prepared with the Press processing technique.

\section{Table 1 - Mean and standard deviation (in parentheses) of degree of conversion (\%) and microshear bond strength (MPa) of resin cement. \\ Ceramic Group \\ (Processing \\ Technique) \\ CAD/CAM \\ Press \\ Microshear Bond Strength Conversion 44.74 (2.96) A 22.18 (1.01) A $19.83(0.42) B$}

Different letters indicate statistically significant differences between mean values (Student's t-test; $p<0.001$ ).

\section{DISCUSSION}

Lithium disilicate-based ceramics have been extensively used to manufacture full and partial monolithic restorations ${ }^{13}$. Two processing techniques are available: pressing and $\mathrm{CAD} /$ CAM technology ${ }^{14-16}$. Pressing technology is a classic methodology used to manufacture duplicate restorations in wax, which is inserted in a special investment cast. Next, flame-volatilized ceramic ingots are injected into the cast under high vacuum so that the shape of the final restoration is identical to that of the wax piece (lost-wax technique) ${ }^{15}$. $\mathrm{CAD} / \mathrm{CAM}$ systems use digital workflow to achieve final restorations through digital casts. Restoration and the milling process are designed in computer software, which provides high precision, efficiency and accuracy, in addition to reducing processing time ${ }^{17}$. Thus, the current study assessed the degree of conversion of resin cement when photoactivated through ceramic prepared using two different processing techniques (Pressing and CAD/CAM) and the microshear bond strength of resin cement to ceramics prepared in these two ways.

It is known that resin cement polymerization can be affected if light does not reach $i^{18}$. Thickness and shade are two of the factors capable of hindering polymerization processes ${ }^{19,20}$. Only discs with similar ceramic thickness $(0.5 \mathrm{~mm})$ and shade $(\mathrm{HV}+1)$ were used in the current study to prevent these factors from affecting the degree of conversion of the resin cement. The photopolymerizing device was placed in contact with the ceramic bars in order to avoid any differences in the distance between the ceramic type and light. The same light-curing unit (LED with $\left.1200 \mathrm{~mW} / \mathrm{cm}^{2}\right)$ and exposure time $(20 \mathrm{~s})$ were used for the resin cement. However, irradiance after the interposition of ceramic discs was attenuated to $1110 \mathrm{~mW} / \mathrm{cm}^{2}$ in the $\mathrm{CAD} / \mathrm{CAM}$ processing technique and to $1020 \mathrm{~mW} / \mathrm{cm}^{2}$ in the Press processing technique. Few studies available in the literature have shown similar outcome for material microstructure. According to Alkadi and Ruse ${ }^{21}$, materials subjected to the pressing technique had increased crystallization rates, whereas Peng et al. ${ }^{22}$ found larger grain size of lithium-disilicate crystals in the pressable form (CAD/CAM $-0.1-1.0 \mathrm{~mm}$ $<$ Pressed $-3-6 \mathrm{~mm}$ ). Both complete crystallization and grain size of lithium-disilicate crystals can potentially affect the mechanical performance of the material. Based on the current results, ceramic manufacturing technique (Press or $\mathrm{CAD} / \mathrm{CAM}$ ) significantly influenced the degree of conversion of the resin cement, which was statistically higher for resin cement photoactivated through ceramic processed with the $\mathrm{CAD} / \mathrm{CAM}$ technique than for resin cement photoactivated through ceramic processed with the press technique.

Bond strength between resin cements and lithium disilicate ceramics is an important factor for ensuring long-lasting dental restorations ${ }^{6}$. Stress transfer to the remnant tooth through the ceramic restoration depends on adequate bonding interface, which can prevent failures ${ }^{23}$. The present study has found differences in the bond strength of resin cement to the lithium disilicate ceramics manufactured with different techniques. Findings in the present study are clinically acceptable, regardless of the material resistance to microshear values (13 $\mathrm{MPa}-30$ $\mathrm{MPa})^{24,25}$. Previous studies have found that material resistance declines over time ${ }^{24,25}$. However, the present study did not use simulated aging to assess 
microshear bond strength, which could be seen as a research limitation. Thus, further studies are needed focused on assessing bond strength after simulated aging based on different processing techniques. Based on results in the current study, the null hypotheses were rejected because different degrees of conversion [1] and microshear bond strengths [2] were found for the two processing techniques.

\section{CONCLUSIONS}

Based on the methodology and materials used, and

FUNDING: None

\section{REFERENCES}

1. Beall AE. Can a new smile make you look more intelligent and successful? Dent Clin North Am 2007; 51:289-297.

2. Chan C, Weber H. Plaque retention on teeth restored with full-ceramic crowns: a comparative study. J Prosthet Dent 1986; 56:666-671.

3. Manicone PF, Rossi Iommetti P, Raffaelli L. An overview of zirconia ceramics: basic properties and clinical applications. J Dent 2007; 35:819-826.

4. Sailer I, Makarov NA, Thoma DS, Zwahlen M, Pjetursson BE. All-ceramic or metal-ceramic tooth-supported fixed dental prostheses (FDPs)? A systematic review of the survival and complication rates. Part I: single crowns (SCs). Dent Mater 2015; 31:603-623.

5. Teichmann M, Göckler F, Weber V, Yildirim M, Wolfart $\mathrm{S}$, Edelhoff D. Ten-year survival and complication rates of lithium-disilicate (Empress 2) tooth-supported crowns, implant-supported crowns, and fixed dental prostheses. J Dent 2017; 56:65-77.

6. Garboza CS, Berger SB, Guiraldo RD, Fugolin AP, GoniniJúnior A, Moura SK, Lopes MB. Influence of surface treatments and adhesive systems on lithium disilicate microshear bond strength. Braz Dent J 2016; 27:458-462.

7. Runnacles P, Correr GM, Baratto Filho F, Gonzaga CC, Furuse AY. Degree of conversion of a resin cement lightcured through ceramic veneers of different thicknesses and types. Braz Dent J 2014; 25:38-42.

8. Rosenstiel SF, Land MF, Crispin BJ. Dental luting agents: A review of the current literature. J Prosthet Dent 1998; 80:280-301.

9. Malament KA, Socransky SS. Survival of Dicor glassceramic dental restorations over 16 years. Part III: effect of luting agent and tooth or tooth-substitute core structure. J Prosthet Dent 2001; 86:511-519.

10. Archegas LR, Freire A, Vieira S, Caldas DB, Souza EM. Colour stability and opacity of resin cements and flowable on results observed in the current study, we conclude that:

1. The degree of conversion of resin cement was higher when it was photoactivated through ceramic prepared with the CAD/CAM technique than through ceramic prepared with the press technique.

2. The microshear bond strength of resin cement was greater when bonded to ceramic prepared with the CAD/CAM technique than ceramic prepared with the press technique.

\section{CORRESPONDENCE}

Prof. Dr. Ricardo Danil Guiraldo

Universidade Pitágoras Unopar - UNOPAR

Rua Marselha, 183

86041140 Londrina, PR Brasil

rdguiraldo@gmail.com

composites for ceramic veneer luting after accelerated ageing. J Dent 2011; 39:804-810.

11. Janda R, Roulet JF, Latta M, Kaminsky M, Ruttermann S. Effect of exponential polymerization on color stability of resin-based filling materials. Dent Mater 2007; 23:696-704.

12. Shimada Y, Yamaguchi S, Tagami J. Micro-shear bond strength of dualcured resin cement to glass ceramics. Dent Mater 2002; 18:380-388.

13. Pieger S, Salman A, Bidra AS. Clinical outcomes of lithium disilicate single crowns and partial fixed dental prostheses: a systematic review. J Prosthet Dent 2014; 112:22-30.

14. Lien W, Roberts HW, Platt JA, Vandewalle KS, Hill TJ, Chu TM. Microstructural evolution and physical behavior of a lithium disilicate glass-ceramic. Dent Mater 2015; 31:928-940.

15. Papadiochou S, Pissiotis AL. Marginal adaptation and CAD-CAM technology: a systematic review of restorative material and fabrication techniques. J Prosthet Dent 2018; 119:545-551.

16. Al Hamad KQ, Al Rashdan BA, Al Omari WM, Baba NZ. Comparison of the fit of lithium-disilicate crowns made from conventional, digital, or conventional/digital techniques. J Prosthodont 2019; 28:e580-e586.

17. Miyazaki T, Hotta Y, Kunii J, Kuriyama S, Tamaki Y. A review of dental CAD/ CAM: current status and future perspectives from 20 years of experience. Dent Mater J 2009; 28:44-56.

18. Reza F, Lim SP. Effects of curing mode of resin cements on the bond strength of a titanium post: An intraradicular study. J Conserv Dent 2012; 15:123-126.

19. Soares CJ, da Silva NR, Fonseca RB. Influence of the feldspathic ceramic thickness and shade on the microhardness of dual resin cement. Oper Dent 2006; 31:384-389.

20. Lee IB, An W, Chang J, Um CM. Influence of ceramic thickness and curing mode on the polymerization shrinkage kinetics of dual-cured resin cements. Dent Mater 2008; 24:1141-1147. 
21. Alkadi L, Ruse ND. Fracture toughness of two lithium disilicate dental glass ceramics. J Prosthet Dent 2016; 116:591-596.

22. Peng Z, Izzat Abdul Rahman M, Zhang Y, Yin L. Wear behavior of pressable lithium disilicate glass ceramic. J Biomed Mater Res B Appl Biomater 2016; 104:968-978.

23. Armstrong S, Geraldeli S, Maia R, Raposo LH, Soares CJ, Yamagawa J. Adhesion to tooth structure: a critical review of "micro" bond strength test methods. Dent Mater 2010; 26:e50-e62.

24. Thurmond JW, Barkmeier WW, Wilwerding TM. Effect of porcelain surface treatment of composite resin bonded to porcelain. J Prosthet Dent 1994; 72:355-359.

25. Kern M, Wegner S. Bonding to zirconia ceramic: adhesion methods and their durability. Dent Mater 1998; 14:64-71. 